\title{
Polyculture of Nile tilapia and shrimp at different stocking densities
}

\author{
Ambrosio Paula Bessa Junior ${ }^{1}$, Celicina Maria da Silveira Borges Azevedo ${ }^{1}$, Frederico Silva \\ Thé Pontes ${ }^{2}$, Gustavo Gonzaga Henry-Silva ${ }^{1}$
}

\footnotetext{
1 Departamento de Ciências Animais - Universidade Federal Rural do Semi-Árido - Mossoró, RN, Brasil.

2 Departamento de Agrotecnologia e Ciências Sociais - Universidade Federal Rural do Semi-Árido - Mossoró, RN, Brasil.
}

\begin{abstract}
This study aimed to evaluate the productivity, growth performance and economic feasibility of polyculture of Nile tilapia Oreochromis niloticus and shrimp Litopenaeus vannamei at different stocking densities. Feed was provided based on fish requirements. The experiment was conducted at the Aquaculture facility of the Universidade Federal Rural do SemiÁrido - UFERSA, in a completely randomized design with five treatments and four replicates each. Treatments consisted of a tilapia monoculture with 2 tilapias. $\mathrm{m}^{-2}$; and polyculture with 2 tilapias. $\mathrm{m}^{-2}$ and $\mathrm{L}$. vannamei at four different densities (3, 6 , 9 and 12 shrimps. $\mathrm{m}^{-2}$ ). The initial individual biomass for fish and shrimp were $1.23 \pm 0.12 \mathrm{~g}$ and $0.133 \pm 0.009 \mathrm{~g}$, respectively. Water quality parameters, temperature, dissolved oxygen, $\mathrm{pH}$ and transparency were monitored. The experiment lasted 120 days and biomass gain was evaluated every two weeks. Final biomass, survival and feed conversion rates were calculated at the end of the experiment. The economic analysis showed that polyculture systems at stocking densities of nine and twelve shrimps. $\mathrm{m}^{-2}$ resulted in higher gross revenue and operational profits of $120.9 \%$ and $97.5 \%$ respectively, with mean gross return significantly higher than the monoculture. The O. niloticus and L. vannamei polyculture in oligohaline water was shown to be technically and economically feasible. These two species can be cultured together, without competing for the same resources, because they have different trophic niche, thus increasing productivity and economic returns for the farmers.
\end{abstract}

Key Words: aquaculture, economic return, growth performance, sustainability

\section{Introduction}

The concept of sustainability must be the basis for planning the wide range of aquaculture activities, including the exploitation of biological resources and social benefits that are generated. Entrepreneurs of the Aquaculture industry should make an effort to effectively implement the sustainability concept, since a productive activity that takes into account only the market and the financial opportunities tends to lead to systems that are not sustainable over time (Boyd, 2003; Henry-Silva \& Camargo, 2008; Valenti et al., 2010).

In this context, polyculture fits the principles of sustainable aquaculture, since it aims at reducing the environmental impact of the activity by improving feeding efficiency and increasing producer income by rearing together two or more species that do not compete for the same feed resources (Cohen \& Ra’anan, 1983; Wohlfarth et al., 1985; Arana, 2004).

In addition, polyculture can also improve water quality, since in monoculture farming systems, the excess nutrients that result from uneaten feed increases the phytoplankton, which, in turn, changes the dissolved oxygen dynamics and brings negative ecological impact to the aquaculture activity itself (Midlen \& Redding, 1998; Lutz, 2003; Henry-Silva \& Camargo, 2008). Therefore, one of the benefits of polyculture is the ability to reduce the pollution resulting from the farming activity, since the residue existing in the ponds can be used by the second species being cultivated.

Despite rapid development, shrimp farming in the Northeast has grown mainly focused on rearing a single species, thus leaving the producers without alternatives to tackle eventual environmental, social and economical problems that should arise. It should be noted that the infrastructure in place for the culture of marine shrimp can also be used for polyculture with tilapia with minor adaptations in the ponds or culture strategy (Bessa Junior et al, 2010). Therefore, the main objective of this study is to evaluate the performance parameters and economic feasibility of a Nile tilapia (O. niloticus) and marine shrimp (L. vannamei) polyculture at different stocking densities.

\section{Material and Methods}

The experiment was conducted at the Aquaculture Department of Universidade Federal Rural do Semi-Árido - 
UFERSA, in Mossoró, RN, Brazil, located at $5^{\circ} 11$ 'S latitude, $37^{\circ} 20^{\prime} \mathrm{W}$ longitude and $18 \mathrm{~m}$ altitude. According to Köppen, the region climate is Bswh', classified as dry and very hot, with two seasons, dry season from June to January and rainy, from February to May (Carmo Filho et al., 1991).

The experiment lasted 124 days for the shrimps and $105 \mathrm{~d}$ for the fish, since the shrimps were stocked 19 days before the fish in order to adapt to low salinity. The experimental units consisted of individual brick ponds with $15 \mathrm{~m}^{2}$ area. The water from a pond with $30 \mathrm{~cm}$ transparency (measured by Secchi disk) and greenish color that resulted from the previous cultures, which is ideal for fish and shrimp (Boyd, 1990), was inoculated before the beginning of the trial. Half of the brick pond capacity was filled with this water and the other half with water from a tubular well with salinity of about $3 \mathrm{~g} / \mathrm{L}$. The phytoplankton community was maintained by adding urea and triple super-phosphate-based chemical fertilizer or water renewal when deemed necessary.

The experimental design was completely randomized with five treatments and four replicates (Table 1). The control group consisted of a tilapia monoculture (2 tilapias. $\mathrm{m}^{-2}$ ) and the experimental treatments consisted of four polycultures, where tilapia density remained constant (2 tilapias. $\mathrm{m}^{-2}$ ), but shrimp was introduced at densities of 3, 6, 9 and 12 shrimps. $\mathrm{m}^{-2}$. Tilapia was considered the main culture, and feed was supplied based on the biomass and nutritional requirements of the fish. Dry feed containing $32 \%$ crude protein was supplied during the first 30 days of culture and, thereafter, extruded feed also containing 32\% crude protein was offered three times daily, based on $10 \%$ of fish biomass, which was determined by fortnight sampling. The initial biomass (initial weight) of tilapia and shrimp was $1.23 \pm 0.12 \mathrm{~g}$ and $0.133 \pm 0.009 \mathrm{~g}$, respectively.

The temperature $\left({ }^{\circ} \mathrm{C}\right), \mathrm{pH}$, oxygen $(\mathrm{mg} / \mathrm{L})$ and transparency $(\mathrm{cm})$ values were measured biweekly in the ponds, totaling 8 measurements for each parameter during the trial period. On the other hand, salinity was measured at the beginning (October, 2008) and at the end (February, 2009) of the trial and values ranged from 3 to $3.5 \mathrm{~g} / \mathrm{L}$.

About ten percent of the animals in the ponds were harvested biweekly with cast nets, with mesh of 8 to $10 \mathrm{~mm}$, to determine growth performance parameters. Weight gain was determined as the difference between current and

Table 1 - Treatment experimental design

\begin{tabular}{lccccc}
\hline Species & \multicolumn{5}{c}{ Stocking } \\
\hline Tilapia & 2 & 2 & 2 & 2 & 2 \\
Shrimp & 0 & 3 & 6 & 9 & 12 \\
Treatments & (2T:0S) & $(2 \mathrm{~T}: 3 \mathrm{~S})$ & $(2 \mathrm{~T}: 6 \mathrm{~S})$ & $(2 \mathrm{~T}: 9 \mathrm{~S})$ & $(2 \mathrm{~T}: 12 \mathrm{~S})$ \\
\hline T - tilapias; S - shrimps. & & & &
\end{tabular}

previous individual biomass, while mean final weight gain was determined dividing final total biomass by the number of surviving animals (n).

$$
F W G=\frac{B I O f}{n}
$$

Growth rate is expressed as the final weight gain per time.

$$
G R=\frac{G M F}{T I M E}
$$

Survival rate, expressed in percentage, was calculated based on the amount of harvested animals divided by the number of stocked individuals and multiplied by 100 .

$S R(\%)=\frac{n \text { end }}{n \text { initial }} \times 100$

Production was obtained by summing the weight in $\mathrm{kg}$ of all harvested animals and extrapolated to a one-hectare area.

$$
P=\frac{B I O f}{n} \times 100
$$

Apparent feed conversion rate (AFCR) was calculated based on the total feed offered divided by the final minus initial biomass (fish + shrimp).

$$
A F C R=\frac{\text { ration }}{B I O f-B I O i}
$$

All costs were calculated at the end of the productive cycle. The costs with supplies and feed were the market prices practiced by each manufacturer. The product final price was the market price of fish and shrimp practiced in the states of Rio Grande do Norte, Ceará and Paraíba, which was obtained by informal interviews with the producers. The price was calculated based on individual weights. The cost analysis of this study is expressed as total expenses (total cost) per hectare of cultivated area, including fixed and variable costs.

Correspondingly, the revenue refers to the amount of production of one hectare of the series in question. Gross revenue (GR), expressed as the production value per hectare, taken as the price paid to the farmer in this region during 2010; operational profit (OP), expressed as the difference between GR per hectare; and total operational costs (TCop) were considered as measures of economic output.

$$
O P=G R-T C o p
$$

Return index (RI) is defined as gross revenue (GR) divided by total operational costs (TCop), i.e., producer gross income for each Brazilian Real spent with total operational costs, $R I=\frac{G R}{T C o p}$ and the profitability index 
(PI), which unlike the previous index, expresses how much the producer can profit from each Real of gross revenue (GR) and thus, the index is calculated by dividing operational profit (OP) by gross revenue, $P I=\frac{O P}{G R}$.

Normality and homoscedasticity of the final biomass, survival, feed conversion rate (FCR) and economical analysis data were tested by the D'Agostinho and Bartlett tests, respectively. The means that presented normal distribution and homogeneous variance were submitted to analysis of variance (one-way ANOVA) and Tukey test to identify significant differences $(\mathrm{P}<0.05)$ between treatments. The physico-chemical and individual biomass variables, which displayed normal distribution and homogenous variance, were submitted to rm-ANOVA at different time intervals (15, 30, 45, 60, 75, 90, 105 and 120 days) and Tukey test to determine significant differences $(\mathrm{P}<0.05)$ between treatments. Individual biomass levels of fish and shrimp were assessed by multiple comparisons of means and orthogonal contrasts of the effects: linear, quadratic and cubic, according to degrees of freedom, using the feature PROC UNIVARIATE of the software SAS (Statistical Analysis System, version 6.10).

\section{Results and Discussion}

Limnological variables and temperature values, in the morning and afternoon, were not significantly different $(\mathrm{P}>0.05$ ) between treatments (Figure 1 ). Water temperature varied from $27 \pm 0.67$ to $31 \pm 0.71{ }^{\circ} \mathrm{C}$, within the range recommended by Brock \& Main (1994). Kubitza (2000) stated that the range of thermal comfort for tilapia lies between 27 and $32{ }^{\circ} \mathrm{C}$, very close to the values reported in this study, and that temperature outside this optimum range cause decreased appetite and growth.

The lowest and highest dissolved oxygen values observed were $5.5 \pm 2.0 \mathrm{mg} / \mathrm{L}$ and $14.0 \pm 1.9 \mathrm{mg} / \mathrm{L}$ in the morning and afternoon, respectively. The dissolved oxygen levels observed in both periods were above the values considered ideal for fish (5 mg. $\mathrm{L}^{-1}$ ) and shrimp (3.5 mg. $\left.\mathrm{L}^{-1}\right)$ growth (Ross \& Ross, 1983; Boyd, 1990). Probably, these higher dissolved oxygen levels observed in the afternoon are because of increased primary production due to greater light incidence during this period.

Water $\mathrm{pH}$ varied between $8.0 \pm 0.18$ and $8.8 \pm 0.24$ during the experimental period. Both species, fish and shrimp, tolerate pH varying between 6.0 and 9.0 (Boyd, 1990; Arana, 1997), while the ideal and satisfactory $\mathrm{pH}$ ranges for fish farming varies from 7.0 to 8.5, and from 6.5 to 9.5 (SipaúbaTavares, 1994), respectively. Marine shrimp ideal pH ranges from 8.0 to 8.5 (Igarashi, 1995). Therefore, the $\mathrm{pH}$ values of this study were within the recommended range for the culture of O. niloticus and L. vannamei. In general, the $\mathrm{pH}$ values changed very little between treatments. This fact is probably due to high buffering capacity of the water in the culture ponds. It should be noted that the wide variation of dissolved oxygen levels between the afternoon and morning is probably the result of phytoplankton photosynthesis. Phytoplankton tends to raise water $\mathrm{pH}$, especially during the afternoon, due to $\mathrm{CO}_{2}$ assimilation; however, the $\mathrm{pH}$ remained relatively steady throughout the experiment (Figure 1).

From the fourth fortnight onward, water transparency values started to decrease for all treatments, but only on the fifth fortnight were transparency values in the monoculture significantly lower than the values obtained for the polycultures at densities of 6, 9 and 12 shrimps.m ${ }^{-2}$ (Figure 1 ). This decreasing transparency, from the fourth fortnight on was probably associated with increasing phytoplankton density in the ponds, since the levels of dissolved oxygen observed in the afternoon were also high. Candido et al (2006) while studying a tilapia and marine shrimp polyculture also reported high transparency at the beginning of the experiment, probably due to use of well water with low nutrient concentrations that resulted in low primary productivity of the system. This result corroborates the present study, where well water was also used in the ponds. Salinity, determined only at the beginning and end of the experiment, varied between 3.0 and $3.5 \mathrm{~g} / \mathrm{L}$. According to Barbieri \& Ostrensky (2002), the shrimp L. vannamei is a euryhaline species, capable of tolerating a wide range of salt water concentrations.

Generally, the polyculture with shrimp, regardless of the density, did not significantly affect mean individual tilapia biomass. The mean final biomass values for the tilapia were $160.6 \pm 4.6 \mathrm{~g}$ (2T:0S), $164.8 \pm 13.8 \mathrm{~g}$ (2T:3S), $183.6 \pm 1.16 \mathrm{~g}$ (2T:6S), $161.5 \pm 3.9 \mathrm{~g}(2 \mathrm{~T}: 9 \mathrm{~S})$ and $168.2 \pm 3.6 \mathrm{~g}$ (2T:12S) (Figure 2). Candido et al. (2006), who studied $O$. niloticus and L. vannamei polyculture in fresh water during 120 days, reported mean values of individual final biomass of 226.68 (2T:4S), 220.43 (2T:8S) and $257.00 \mathrm{~g}$ (2T:12S). This higher mean individual biomass compared with the present study is probably due to a longer rearing period.

The shrimp individual biomass values were significantly different between treatments and over time as well, from the second fortnight. In general, shrimp individual biomass decreased as the stocking density increased. At the end of the experiment (6th fortnight), shrimp individual biomass was significantly higher for treatment 2T:3S (16.1 $\pm 0.6 \mathrm{~g})$ compared with treatments $2 \mathrm{~T}: 9 \mathrm{~S}(9.6 \pm 1.2 \mathrm{~g})$ and $2 \mathrm{~T}: 12 \mathrm{~S}$ 
호2T:0S 모2T:3S 조2T:6S 조2T:9S 푸2T:12S
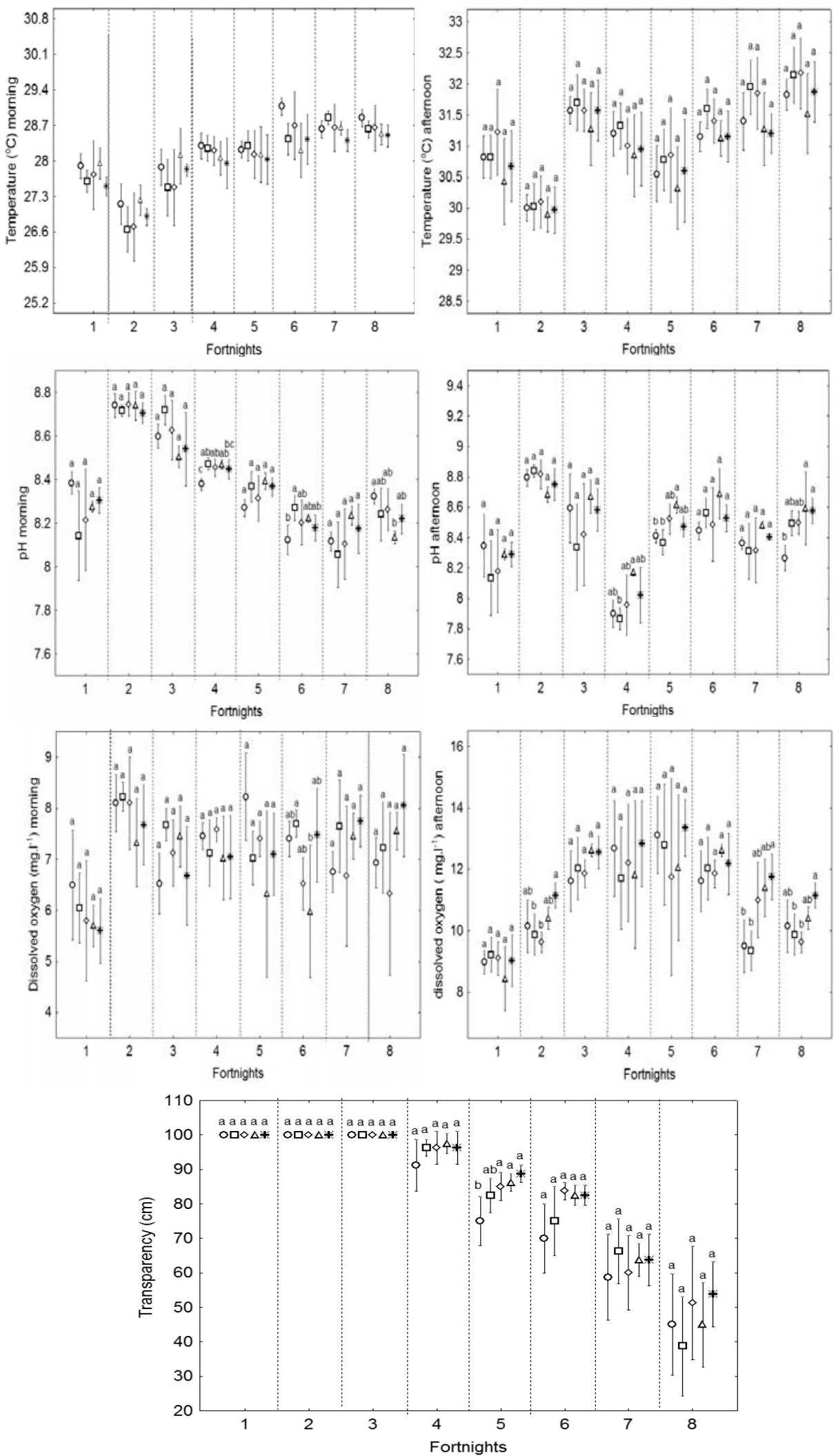

Different letters indicate significant differences by the Tukey test $(\mathrm{P}<0.05)$.

$\mathrm{T}$ - tilapias; $\mathrm{S}$ - shrimps.

Figure 1 - Mean and standard deviation values of temperature, $\mathrm{pH}$, dissolved oxygen and transparency for the different treatments, collected biweekly during the period. 

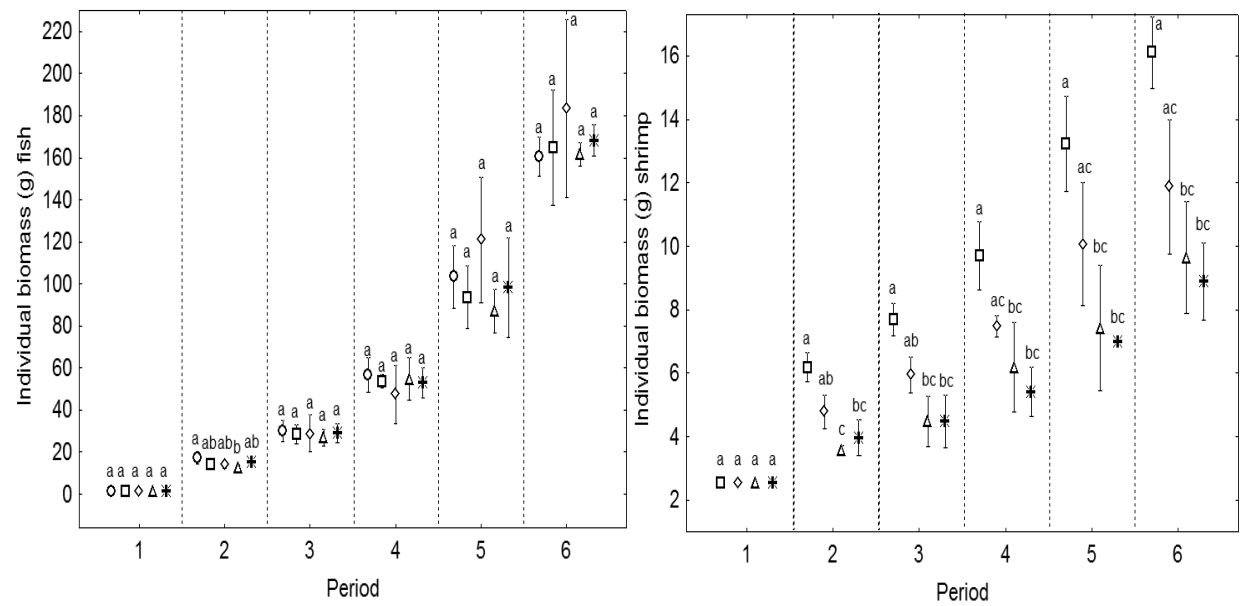

Different letters indicate significant differences by the Tukey test $(\mathrm{P}<0.05)$. $\mathrm{T}$ - tilapias; S - shrimps.

Figure 2 - Mean and standard deviation values of individual biomass of tilapia O. Niloticus and shrimp L. vannamei resulting from six measurements biweekly performed during the experiment.

( $8.9 \pm 0.8 \mathrm{~g})$. However, the values were not significantly different between treatment 2T:6S $(11.87 \pm 1.5 \mathrm{~g})$ and the other treatments. Mean values of shrimp final individual biomass (6th fortnight) for treatments 2T:3S and 2T:6S were similar to the ones reported by Candido et al. (2006) for $O$. niloticus and $L$. vannamei polyculture at densities of 2 tilapias.m ${ }^{-2}$ and 4 (13.2 g), 8 (14.2 g) and 12 (14.0 g) shrimps.m ${ }^{-2}$. Wohlfarth et al. (1985) concluded that fish and shrimp growth rates are not interdependent in polyculture systems. Some studies have shown that in polyculture, the development of shrimp is more influenced by their own population density than the density of fish populations (New, 1995). In fact, in the present study, high shrimp stocking densities (2T:9S and 2T:12S) yielded final individual biomass values significantly lower compared with low shrimp density (2T:3S). This fact was probably related to the reduced feed supply and/or intraspecific competition in ponds where shrimp density was high.

There were no significant differences between treatments for fish total biomass (Figure 3). Therefore, it can be concluded that polyculture with shrimp did not affect Nile tilapia yield. Santos \& Valenti (2002) also concluded that shrimp (M. rosenbergii) and tilapia polyculture did not affect fish production. In a 175-day assay, these authors obtained average production of $3445 \mathrm{~kg} / \mathrm{ha}$ for tilapia monoculture and average production varying from 3671 to $3857 \mathrm{~kg} / \mathrm{ha}$ for tilapia polyculture. In the present study, average productivity was $2701 \pm 102 \mathrm{~kg} /$ ha for monoculture and varied between $2562 \pm 173 \mathrm{~kg} / \mathrm{ha}$ (2T:6S) and 2814 \pm 158 $\mathrm{kg} / \mathrm{ha}$ (2T:12S) for polyculture. The lower yield obtained in our study may be due to the shorter period of the study: 105 days compared with 175 .

There were no significant differences for total shrimp biomass between treatments, mainly due to the large variation range observed between the replicates of four treatments, especially in the case of treatment 2T:9S (Figure 3). However, the highest mean values of total biomass were observed in the treatments at higher stocking density (185 $\pm 46.3 \mathrm{~kg} / \mathrm{ha}$ for $2 \mathrm{~T}: 3 \mathrm{~S}$; $240 \pm 78.1 \mathrm{~kg} / \mathrm{ha}$ for $2 \mathrm{~T}: 6 \mathrm{~S}$; $389 \pm 161.0 \mathrm{~kg} / \mathrm{ha}$ for $2 \mathrm{~T}: 9 \mathrm{~S}$ and $383 \pm 94.4 \mathrm{~kg} / \mathrm{ha}$ for $2 \mathrm{~T}: 12 \mathrm{~S}$ ). Simão (2008) reported average productivity of $305 \mathrm{~kg} / \mathrm{ha}$ while studying tilapia (2 tilapias. $\mathrm{m}^{-2}$ ) and marine shrimp (5 shrimps. $\mathrm{m}^{-2}$ ) polyculture during a 95-day assay, a lower productivity than that achieved in this study at stocking density of 6 shrimps.m ${ }^{-2}$.

There were no significant differences for fish survival rates between different treatments. Tilapia final survival rate in monoculture ( $84 \pm 3.1 \%)$ was similar to the survival rate

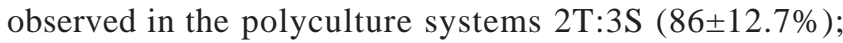
2T:6S (73 $\pm 10.6 \%)$; 2T:9S ( $86 \pm 2.9 \%)$ and 2T:12S (86 $\pm 4.4 \%)$ (Figure 4). Fish average survival rates were similar to the results reported by García-Pérez et al. (2000) between 84 and $85 \%$ for tilapia O. niloticus at the following densities: 7 shrimps (M. rosenbergii) and 1 tilapia. $\mathrm{m}^{-2}$ and higher than the values reported by Santos \& Valenti (2002), between 64 and $72 \%$ for tilapia-shrimp polyculture at densities of 2, 4 and 6 shrimps (M. rosenbergii) and 1 tilapia. $\mathrm{m}^{-2}$. The high survival rates obtained in the present study indicate that management was adequate and water physico-chemical parameters were within the ideal range for the cultivated species. 

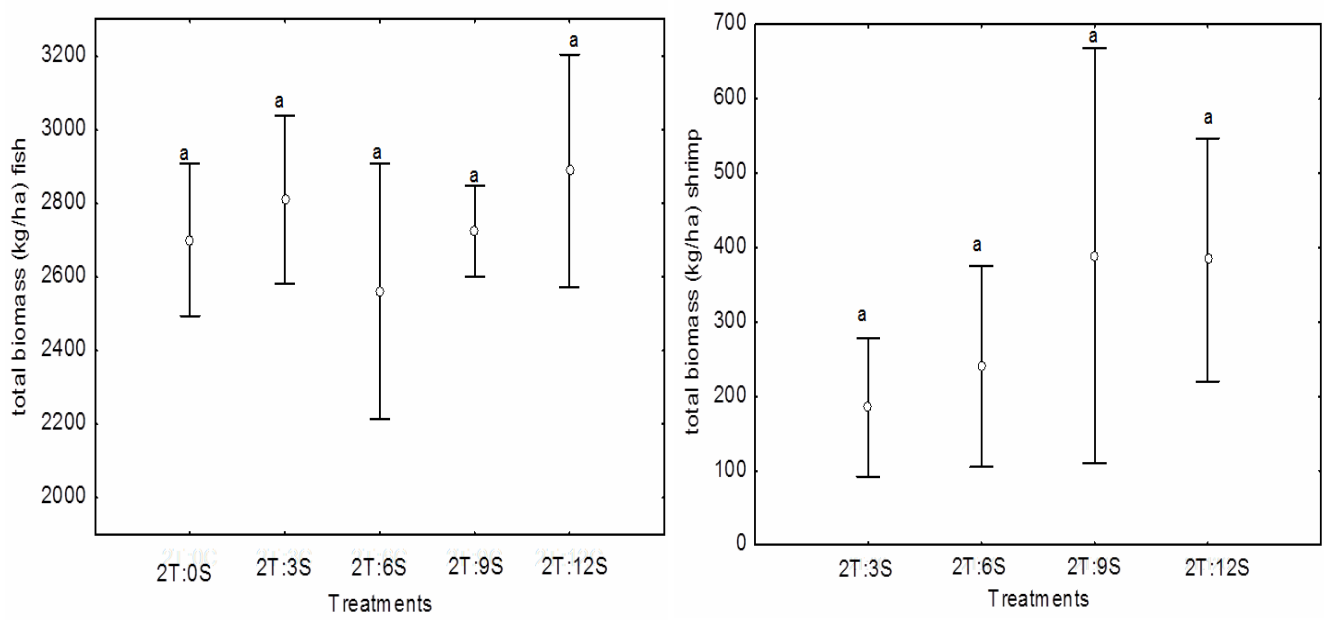

Different letters indicate significant differences by Tukey $(\mathrm{P}<0.05)$. $\mathrm{T}$ - tilapias; $\mathrm{S}$ - shrimps.

Figure 3 - Mean and standard deviation values of total final biomass (kg/ha) for tilapia O. niloticus and shrimp L. vannamei reared in mono and polyculture systems.
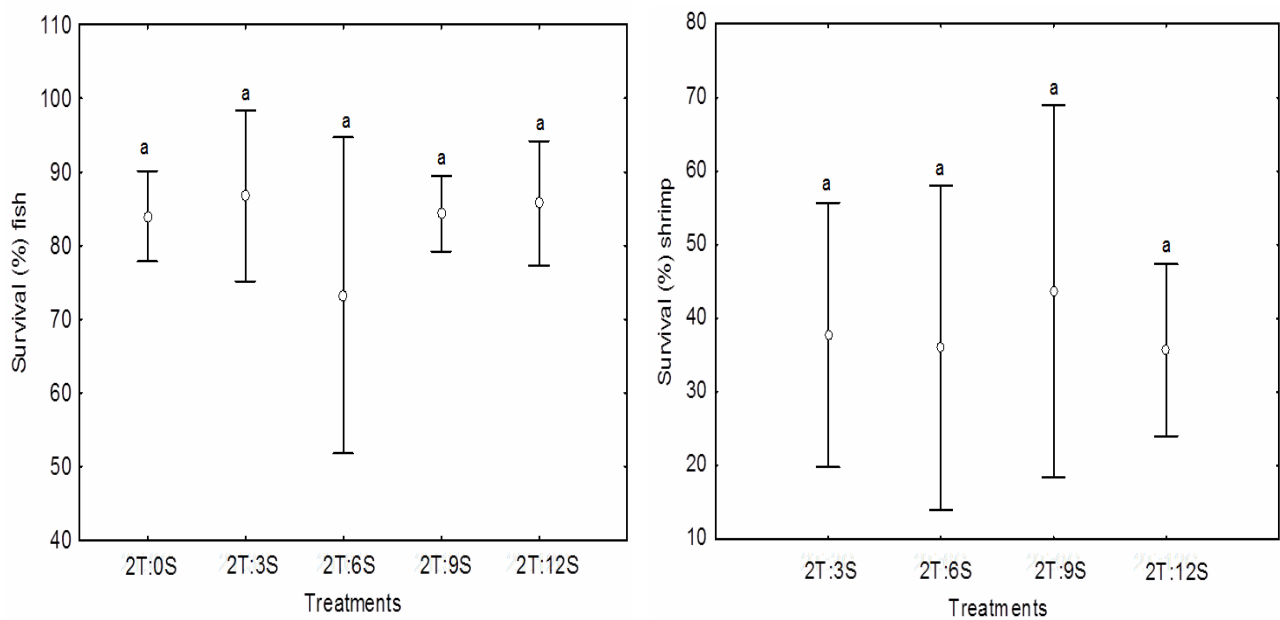

Different letters indicate significant differences by Tukey $(\mathrm{P}<0.05)$.

$\mathrm{T}$ - tilapias; $\mathrm{S}$ - shrimps.

Figure 4 - Mean and standard deviation values of final survival (\%) rates for tilapia O. niloticus and shrimp L. vannamei cultivated in mono and polyculture systems.

There were also no significant differences for final survival rate of shrimp grown at different densities in polyculture systems. However, unlike the high survival rates observed for tilapia, shrimp survival rates were low (38 $\pm 8.8 \%$ for $2 \mathrm{~T}: 3 \mathrm{~S} ; 36 \pm 12.4 \%$ for $2 \mathrm{~T}: 6 \mathrm{~S} ; 44 \pm 14.6 \%$ for $2 \mathrm{~T}: 9 \mathrm{~S}$ and $36 \pm 6.4 \%$ for $2 \mathrm{~T}: 12 \mathrm{~S}$ ) (Figure 4 ). Candido et al (2006) studied a L. vannamei and O. niloticus polyculture at densities of 2 tilapias. $\mathrm{m}^{-2}$ and 4,8 and 12 shrimps.m ${ }^{-2}$, and reported average shrimp survival rates of $83.3 \%, 88.5 \%$ and $86.1 \%$, respectively. The high mortality rate in this study probably happened at the start of the experiment, since the shrimps were not fed during the adaptation period.

No statistical differences were observed for feed conversion rate (FCR) between mono and polyculture systems (Figure 5). Average FCR was 1.08 $\pm 0.48 / 1$, i.e., $1.08 \mathrm{~g}$ of feed was consumed to produce $1 \mathrm{~kg}$ of fish and shrimp biomass. Santos \& Valenti (2002), while studying tilapia and prawn $M$. rosenbergii polyculture reported significant differences for this variable: $1.94 ; 1.94$ and 1.86 at the following densities 1 tilapia. $\mathrm{m}^{-2}$ and 2, 4 and 6 shrimps. $\mathrm{m}^{-2}$, respectively. Possibly, the low FCR of this study is due to the volume of biomass produced during a short growing season, when environmental conditions are favorable for producing fish and shrimp of the $L$ vannamei species.

The average selling prices of the products used in the economical feasibility study were the prices practiced by the market in 2010 (Table 2). Ten percent was added to and subtracted from the probable target value to reach more 
optimistic and pessimistic values, respectively. The prices of shrimp varied with average final weight, i.e., $\mathrm{R} \$ 1.10 / \mathrm{g}$ for small shrimp (Between 7.5 and 9.0 grams) and $\mathrm{R} \$ 0.80 / \mathrm{g}$ for large shrimp (above 9.0 grams).

The variable operational costs between polyculture and monoculture systems differ, mainly, with respect to feeding and additional expenses to introduce shrimp postlarvae at different densities in each treatment, as these values focused on the total operational costs (Table 3).

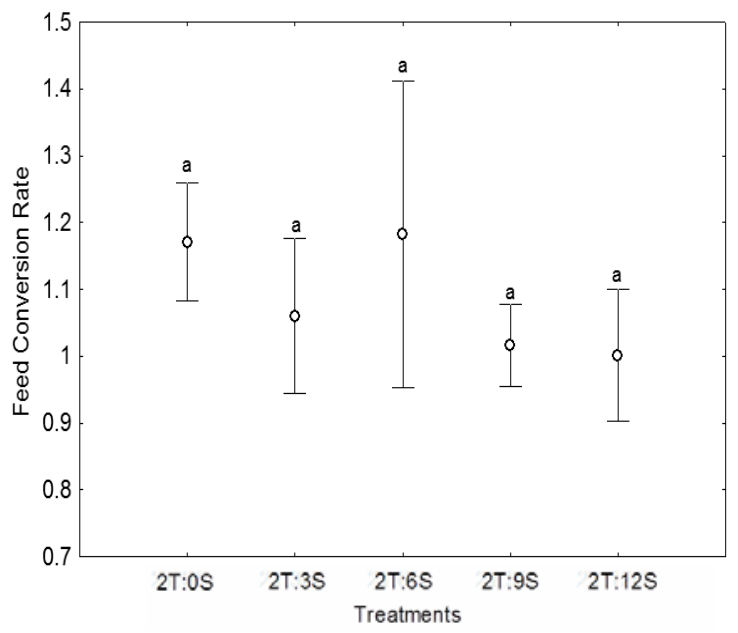

Different letters indicate significant differences by Tukey test $(\mathrm{P}<0.05)$. $\mathrm{T}$ - tilapias; S - shrimps.

Figure 5 - Mean and standard deviation values for apparent feed conversion rate for Nile tilapia O. niloticus and marine shrimp L. vannamei in mono and polyculture systems.

Table 2 - Average selling prices of tilapia and shrimp practiced by the market in 2010

\begin{tabular}{lccc}
\hline Individual biomass $(\mathrm{g})$ & Pessimistic & Probable & Optimistic \\
\cline { 2 - 4 } & $\mathrm{R} \$ / \mathrm{kg}$ & $\mathrm{R} \$ / \mathrm{kg}$ & $\mathrm{R} \$ \mathrm{~kg}$ \\
\hline Tilapia $>150$ & 4.50 & 5.00 & 5.50 \\
Shrimp $>14<16$ & 10.30 & 11.40 & 12.50 \\
Shrimp $>12<14$ & 9.60 & 10.70 & 11.80 \\
Shrimp $>10<12$ & 8.50 & 9,40 & 10.30 \\
Shrimp $>8<10$ & 7.50 & 8.30 & 9.10 \\
Shrimp $<8$ & 7.60 & 8.50 & 9.30 \\
\hline
\end{tabular}

The analysis of production costs shows that the fixed costs to produce fish in net-cages represent between 8 and $12 \%$ of the total production cost (Carneiro et al., 1999; Ono \& Kubitza, 1999; Vera-Calderón, 2003). These values are well below the mean values found in this study, where the fixed costs represent $34 \%$ of the total production costs for monoculture; and 35\% for 2T:3S; 35\% for 2T:6S; 35\% for $2 \mathrm{~T}: 9 \mathrm{~S}$ and $36 \%$ for $2 \mathrm{~T}: 12 \mathrm{~S}$ in the polyculture systems. However, it should be emphasized that the fixed costs with depreciation and maintenance of the installations for excavated ponds are much higher than the net-cage systems. In this study, feed was the item with the greatest participation in the variable costs, ranging from $36.7 \%$ in polyculture to $38.6 \%$ in monoculture systems.

For the monoculture, gross revenue $(\mathrm{R} \$ 13,857.00)$ and operational profit (R \$ 3179.60) were significantly lower compared with the values obtained for polyculture treatments at higher shrimp density ( $\mathrm{R} \$ 18,339.00$ and $\mathrm{R} \$ 7,025.90$ for 2T:9S; R\$ 17,730.00 and R \$ 6,281.50 for 2T:12S). However, the differences were not significant for these economic variables when monoculture was compared with polyculture at lower shrimp densities (2T:3S and 2T:6S) (Figure 6). But, when considering the optimistic scenario for the marketing values of fish and shrimp (Table 5), it can be seen that the gross revenue $(\mathrm{R} \$ 15,242.00)$ and operational profit $(\mathrm{R} \$ 4,565.00)$ for monoculture were not significantly different compared with the polyculture at densities 2T:9S and 2T:12S.

Although production was not statistically different between treatments, gross revenue varied, since shrimp was paid according to size, and therefore, profit also varied. This fact was confirmed by Bejerano (2001), who found that the net income from shrimp can be maximized when cultivated in polyculture with tilapia.

Return and profitability indexes were significantly lower in the monoculture, compared with the results obtained in tilapia-shrimp polyculture at density of 9 shrimps. $\mathrm{m}^{-2}$ (2T:9S) (Figure 7). This difference is mainly due to the large variation observed for shrimp survival rate in treatment $2 \mathrm{~T}: 9 \mathrm{~S}$, which resulted in high gross revenue

Table 3 - Variable, fixed and total operational (VCop, FCop and TCop, respectively) costs ofa mono and polyculture of tilapia O. niloticus and shrimp L. vannamei

\begin{tabular}{lccccc}
\hline Treatments & VCop & $\%$ & FCop & $\%$ & TCop \\
\hline 2T:0S & $\mathrm{R} \$ 7037.03$ & $65.52 \%$ & $\mathrm{R} \$ 3702.48$ & $34.48 \%$ & $\mathrm{R} \$ 10739.51$ \\
$2 \mathrm{~T}: 3 \mathrm{R}$ & $\mathrm{R} \$ 7103.60$ & $64.68 \%$ & $\mathrm{R} \$ 3878.68$ & $35.32 \%$ & $100 \%$ \\
$2 \mathrm{~T}: 6 \mathrm{~S}$ & $\mathrm{R} \$ 7180.10$ & $64.93 \%$ & $\mathrm{R} \$ 3878.68$ & $35.07 \%$ & $\mathrm{R} \$ 10982.28$ \\
$2 \mathrm{~T}: 9 \mathrm{R}$ & $\mathrm{R} \$ 6934.20$ & $64.13 \%$ & $\mathrm{R} \$ 3878.68$ & $35.87 \%$ & $\mathrm{R} \$ 11058.78$ \\
2T:12S & $\mathrm{R} \$ 7147.20$ & $64.82 \%$ & $\mathrm{R} \$ 3878.68$ & $35.18 \%$ & $100 \%$ \\
\hline
\end{tabular}

T - tilapias; S - shrimps. 

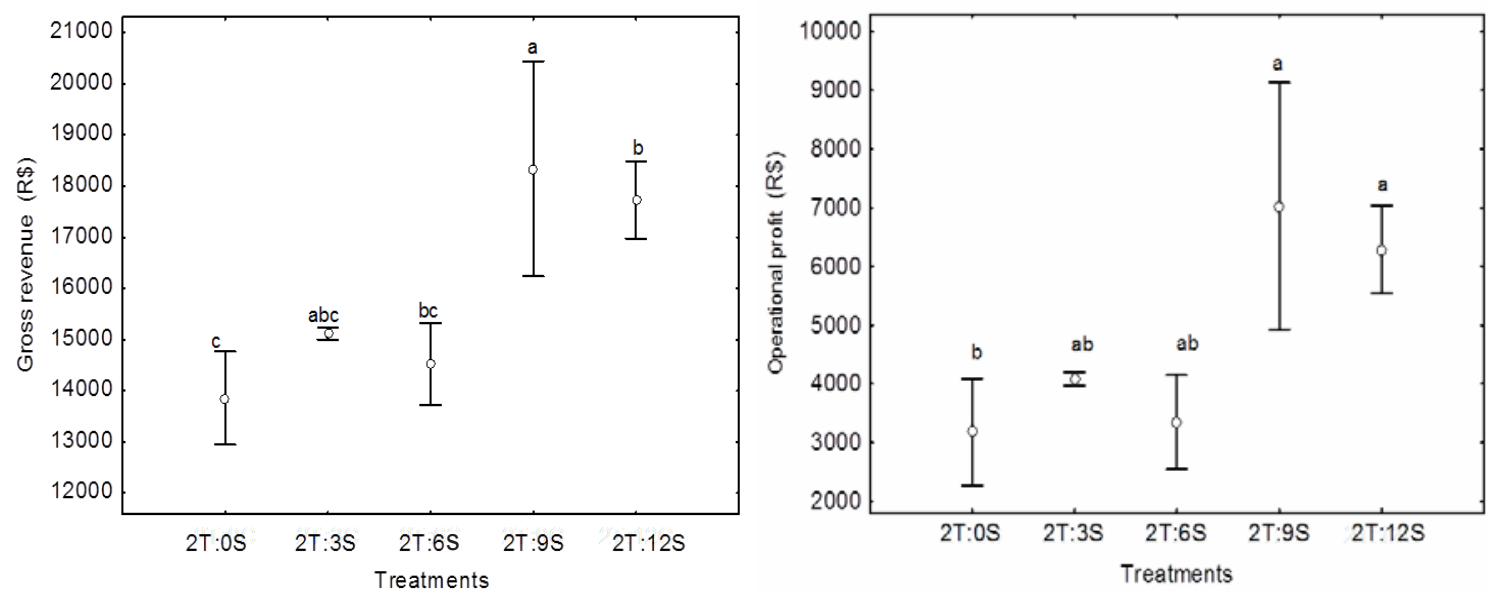

Different letters indicate significant differences by Tukey $(\mathrm{P}<0.05)$.

T - tilapias; S - shrimps.

Figure 6 - Mean and standard deviation values of gross revenue (GR) and operational profit (OP) obtained for Nile tilapia O. niloticus and marine shrimp L. vannamei in mono and polyculture systems.
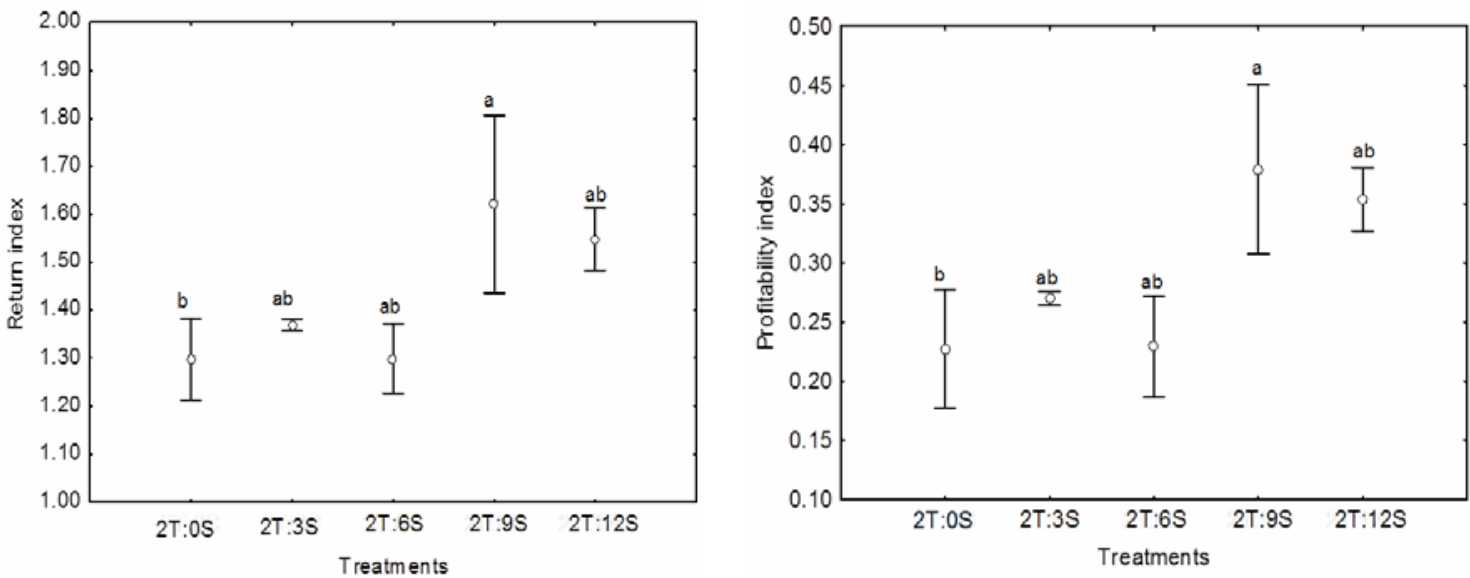

Different letters indicate significant differences by Tukey $(\mathrm{P}<0.05)$.

$\mathrm{T}$ - tilapias; $\mathrm{S}$ - shrimps.

Figure 7 - Mean and standard deviation values of return index (RI) and profitability index (PI) obtained for Nile tilapia O. niloticus and marine shrimp L. vannamei in mono and polyculture systems.

and operational profit. Shang \& Merola (1987) also stated that increased size at selling time, as well as higher survival rates, are strategies that minimize production costs per unit and increase return on invested capital.

\section{Conclusions}

Different shrimp stocking densities did not influence total biomass gain of Nile tilapia. However, individual biomass gain of shrimp varied inversely with shrimp stocking density; therefore, shrimp biomass increased at lower stoking density. The polyculture of Nile tilapia O. niloticus, and marine shrimp L. vannamei in oligohaline water proved to be technically feasible, since one species did not interfere with the development of the other, and from the economical viewpoint, polyculture displayed better economical and performance indicators, in comparison with monoculture.

\section{Acknowledgments}

The authors would like to express their gratitude to the Dr. Felipe Ribeiro and Natália Celedonio, responsible for the Aquaculture Sector at UFERSA, for helping in the field activities; to the Fishery Engineer Yuri Andrade, for helping with sample collection and measurements; to the companies AQUANORTE and LARVI, for donating the fish and shrimp, respectively; and to all the undergraduate students of Fishery Engineering at UFERSA, who somehow contributed to this study. 


\section{References}

ARANA, L.V. Princípios químicos da qualidade da água em aqüicultura. Florianópolis: UFSC, 1997. 166p.

ARANA, L.V. Fundamentos de aqüicultura. Florianópolis: UFSC, 2004. 349p.

BARBIERI JÚNIOR, R.C.; OSTRENSKY, A. Camarões marinhos Engorda. Viçosa, MG: Aprenda Fácil, 2002. v.2, 311p.

BEJERANO A. Policultivo? Oportunidad o riesgo? Aquacultura del Equador, v.7, p.41-43, 2001.

BESSA JUNIOR, A.P.; AZEVEDO, C.M.S.B.; HENRY-SILVA, G.G. Sustentabilidade do policultivo de peixes e camarões. Boletim da Sociedade Brasileira de Limnologia, v.38, n.2, p.1-6, 2010.

BOYD, C.E. Water quality in ponds for aquaculture. Auburn. Alabama: Alabama Agricultural Experiment Station, 1990. 482p.

BOYD, C.E. Guidelines for aquaculture effluent management at the farm-levels. Aquaculture, v.226, p.101-112, 2003.

BROCK, J.A.; MAIN, K. A guide to the common problems and diseases of cultured Paenaeus vannamei. Honolulu: The Oceanic Institute, 1994. 242p.

CANDIDO, A.S.; MELO JÚNIOR, A.P.; COSTA, O.R. et al. Efeito de diferentes densidades na conversão alimentar da tilápia Oreochromis niloticus com o camarão marinho Litopenaeus vannamei em sistema de policultivo. Revista Ciência Agronômica, v.36, n.3, p.279-284, 2006.

CARMO FILHO, F.; ESPÍNOLA SOBRINHO, J.; MAIA NETO, J.M. Dados climatológicos de Mossoró: um município semi-árido nordestino. Mossoró: ESAM., 1991. 121p. (Coleção Mossoroense, C. 30$)$.

CARNEIRO, F.B.; MARTINS, M.; CYRINO, J.E.P. Estudo de caso da criação comercial da tilápia em tanque-rede - Avaliação Econômica. Informações Econômicas, v.29, n.8, p.52-61, 1999.

COHEN,D.; RA'ANAN, Z. The production of the freshwater prawn Macrobrachium roseberguii in Israel. III Density effects of all-male tilapia hibrid on prawn yield caracteristics in policulture. Aquaculture, n.35, p.57-71, 1983.

COSTA, J.E.L. A carcinicultura na região de Mossoró: período de 2002 a 2005. 56f. 2005. Monografia (Especialização em Carcinicultura) - Universidade Federal Rural do Semi-Árido, Mossoró.

GARCÍA-PÉREZ, A.; ALSTON, D.E; CORTÉZ-MALDONADO, R. Growth, survival, Yield, and size distribuitions of freshwater prawn Macrobrachium rosenbergii and tilapia Oreochromis niloticus in polyculture and monoculture systems in Puerto Rico. Journal of World Aquaculture Society, v.31, n.3, p.446-451, 2000.

HENRY-SILVA, G.G.; CAMARGO, A.F.M. Impacto das atividades de aqüicultura e sistemas de tratamento de efluentes com macrófitas aquáticas. Boletim do Instituto de Pesca, v.34, n.1, p.165-175, 2008.

IGARASHI, M.A. Estudo sobre o cultivo de camarões marinhos. Fortaleza: SEBRAE, 1995. 66p.

KUBTZA, F. Transporte de peixes vivos. In: WORKSHOP INTERNACIONAL DE AQÜICULTURA, 1., 1997, São Paulo. Anais... São Paulo, 1997. p.72-89.
KUBITZA, F. Tilápia: tecnologia e planejamento na produção comercial. Jundiaí: F. Kubitza, 2000. 285p.

LUTZ, C.G. Polyculture: principles, practices, problems and promise. Aquaculture Magazine, n.29, p.34-39, 2003.

MIDLEN, A.; REDDING, T. Environmental management for aquaculture. Netherlands: Kluwer Academic Publishers, 1998. 223p.

NEW, M.B. Status of freshwater prawn farming: a rewiew. Aquaculture Research, n.26, p.1-54, 1995.

NORIEGA, E.A.A.; MURUETA, J.H.C.; ADAME, C.R.A. Mejoras en el manejo de estanques para el cultivo de camarón blanco Penaeus vannamei en una granjacomercial de Sonora, México. Aquanoticias, Boletín de capítulo Latino americano de la Sociedade Mundial de Acuicultura, Latin American Chapter, World Aquaculture Society, n.3, v.2, p.17-18,1998.

ONO, E.; KUBITZA, F. Cultivo de peixes em tanque-rede. 2.ed. Jundiai: ESALQ/USP, 1999. 68p.

ROSS, B.; ROSS, L.G. The oxygen requirements of Oreochromis niloticus underadverse conditions. In: INTERNATIONAL SYMPOSIUM ON TILAPIA IN AQUACULTURA, 1983, Nazareth, Israel. Proceedings... Tel Aviv, Israel: Tel Aviv University Press, 1983. p.134-143.

SANTOS, M.J.M.; VALENTI, W.C. Production of Nile Tilapia Oreochromis niloticus and freshwater Prawn Macrobrachium rosenbergii stocked at different densities in polyculture systems in Brazil. Journal of the World Aquaculture Society, v.33, n.3, p.369-376, 2002.

SHANG, Y.C.; MEROLA, N. Manual de economia de la aquicultura. FAO/Programa Cooperativo Gubernamental. Proyecto GCP/RLA/ 075/ITA. Apoyo a las actividades regionales de acuacultura para America Latina y el Caribe. Brasília, 1987.

SIMÃO, B.R. Desempenho produtivo de camarão (Litopenaeus vannamei) e tilápia (Oreochromis niloticus) em mono e policultivo. 2008. 44f. Dissertação (Mestrado em Ciência Animal) - Universidade Federal Rural do Semi-Árido, Mossoró.

SIPAÚBA-TAVARES, L.H. Limnologia aplicada à aquicultura. Jaboticabal: Fundação Universidade Estadual Paulista, 1994. $70 \mathrm{p}$.

VALENTI, W.C. Cultivo de camarões de água doce. São Paulo: Nobel, 1985. 82p.

VALENTI, W.C.; KIMPARA, J.M.; ZAJDBAND, A.D. Métodos para medir asustentabilidade da aqüicultura. Panorama da Aqüicultura, v.20, p.28-33, 2010.

VERA-CALDERÓn, LOT E. [2003]. Análise econômica da criação de tilápias (Oreochromis ssp.) em tanque-rede. Available at: <http://www.civa2003.org>. Accessed on: June 7, 2011.

WANG, J.Q.; LI, D.; DONG, S. et al. Experimental studies on polyculture in closed shrimp ponds: 1 . Intensive polyculture of chinese shrimp (Penaeus chinensis) with tilapia hybrids. Aquaculture, v.163, p.11-27, 1998.

WOHLFARTH, G.W.; HULATA, G.; KARPLUS, I. et al. Polyculture of thefreshwater prawn Macrobrachium rosenbergii in intensively manured ponds andthe effect of strockig rate of prawns and fish on their production characteristics. Aquaculture, v.46, p.142-56, 1985. 